\title{
USE OF DUMMY VARIABLES TO PREDICT GROWTH STRESSES IN Eucalyptus ssp. CLONES ${ }^{1}$
}

\author{
Rafael Beltrame ${ }^{2 *}$, Pedro Henrique Gonzalez Cadermatori ${ }^{3}$, Rafael de Avila Delucis ${ }^{4}$, Darci Alberto Gatto ${ }^{5}$ \\ Clovis Roberto Haselein ${ }^{6}$ and Paulo Renato Schneider ${ }^{6}$

\footnotetext{
${ }^{1}$ Received on 15.01.2015 accepted for publication on 25.10.2016.

${ }^{2}$ Universidade Federal de Pelotas, Centro de Engenharias, Pelotas, RS - Brasil .E-mail: <beltrame.rafael@yahoo.com.br>.

${ }^{3}$ Universidade Federal do Paraná, Programa de Pós-Graduação de Engenharia Florestal, Curitiba-PR - Brasil. E-mail: $<$ pedrocademartori@gmail.com>.

${ }^{4}$ Universidade Federal do Rio Grande do Sul, Programa de Pós-Graduação em Engenharia de Minas, Metalúrgica de Materiais, Porto Alegre-RS - Brasil. E-mail: <r.delucis@hotmail.com>.

${ }^{5}$ Universidade Federal de Pelotas, Engenharia Industrial Madeireira, Pelotas, RS - Brasil. E-mail: <darcigatto@yahoo.com>.

${ }^{6}$ Universidade Federal de Santa Maria, Centro de Ciências Rurais, Departamento de Ciências Florestais, Santa Maria, RS

- Brasil. E-mail: <clovis.haselein@ufsm.br>and <paulors@smail.ufsm.br>.

*Corresponding author.
}

\begin{abstract}
The evaluation of growth stresses in Eucalyptus trees and their influence on both morphological properties of trees and technological properties of wood have been aimed by several studies, which used indirect and nondestructive methods for these evaluations. The present study aimed to estimate growth stresses for woods from Eucalyptus ssp. clones trough some of their dendrometric properties, using Dummy variables. 12 hybrid Eucalyptus clones were evaluated by basic density (BD) and dendrometric properties: diameter at breast height (DBH), bark thickness (BT), height $(\mathrm{H})$ and total volume (VOL). The growth stresses were indirectly evaluated by the longitudinal residual strain (LRS) following the CIRAD-Forêt method. 12 Dummy variables were defined based on the characteristics of each clone. After that, four models were proposed in order to estimate the LRD, using Dummy variables, DBH, H, VOL and BD as independent variables. Among the dendrometric properties, BD was discarded because it does not confer interesting aids to the LRD predict. Among the Dummy variables, clone 9 provided the most discrepant variable. The LRD of the clones were satisfactorily described by the mathematical models, although these values showed significant variability.
\end{abstract}

Keywords: Technological parameters; CIRAD-Forêt method; Mathematical models.

\section{USO DE VARIÁVEIS DUMMY PARA A PREDIÇÃO DE TENSÕES DE CRESCIMENTO EM CLONES DE Eucalyptus spp.}

RESUMO - O presente estudo objetivou estimar as tensões de crescimento da madeira de clones de Eucalyptus spp., por meio de algumas de suas propriedades dendrométricas, utilizando-se de variáveis Dummy. Foram selecionados 12 clones híbridos do gênero Eucalyptus, dos quais foram avaliadas as propriedades dendrométricas: diâmetro a altura do peito (DAP), espessura de casca (EC), altura (H), volume total (VOL); bem como a densidade básica $(D B)$. As tensões de crescimento foram avaliadas de maneira indireta, por meio da deformação residual longitudinal (DRL), medida conforme o método CIRAD-Forêt. Foram definidas 12 variáveis Dummy com base nas características de cada clone. Após, a fim de estimar matematicamente a DRL, foram propostos quatro modelos utilizando-se como variáveis independentes: DAP, H, VOL, DB e as variáveis Dummy. Dentre as propriedades dendrométricas, a DB foi a única descartada por não aportar subsídios interessantes para a predição da DRL. Na comparação entre as variáveis Dummy, o clone 9 deu origem à variável mais discrepante em relação às demais. Contudo, os resultados obtidos indicaram que, embora tenha havido uma variabilidade significativa nos níveis de DRL na comparação entre os diferentes clones, os modelos matemáticos obtidos descreveram satisfatoriamente as tensões de crescimento dos mesmos.

Palavras-chave: Parâmetros tecnológicos; Método CIRAD-Forêt; Modelos matemáticos. 


\section{INTRODUCTION}

Using fast-growing species is one of the most interesting alternatives to reduce the environmental impact caused by the depletion of native forests from tropical countries. In the Brazilian context, for the last decades, exotic species have been inserted in forestry and wood markets, as well as their genetic enhancement in order to obtain both eco-friendly and high quality products. Among the fast-growing species most appreciated, species from Pinus and Eucalyptus genres can be highlighted.

Species from the Eucalyptus genus are widely planted both in temperate and tropical regions, mainly due to both their high productivity in marginal sites and their wide range of useful forestry products (AGGARWAL; CHAUHAN, 2013). These products are related to the cellulose/paper production, reconstituted panels and biomass energy resources. However, in order to obtain products with aggregate value, this raw material is used in form of lumbers, supplying the construction sector with structural pieces.

In this context, the eucalypt wood has intrinsic characteristics, as growth stresses, that are hindering factors and can derail its use. The effects from the release of the growth stresses are responsible for strains that cause top cracks in wood logs and warp in lumbers under dry process, resulting in processing issues and low yield of timber free of defects (AGGARWAL; CHAUHAN, 2013). Then, high growth stresses values are a big part of the processing issues in the lumber production sector in Brazil (ROCHA, 2000). Therefore, to knowledge of the factors that affect the wood quality is essential to increase the aggregate value of the forestry plantations.

The study of growth stresses in eucalypt trees and their influence on both morphological properties of trees and technological properties of wood has been aimed by several researchers, which used an indirect and nondestructive method for this evaluation (CIRADForêt method) to determine these stresses with basis on the longitudinal residual strain - LRS (RAYMOND et al., 2004; BELTRAME et al., 2012; BELTRAME et al., 2013).

Aligned with this, there is the need of statistical tools, which allows specific adjustments with larger precision than the traditional methods. Among these tools, the use of Dummy variables rose to prominence, which can be used to predict growth stresses accounting morphological properties of the trees and technological properties of the wood as independent variables. According to Cunia (1973), the use of Dummy variables to generate linear mathematical models allow to show individual regressions, which were adjusted in a single model from a multiple linear regression.

This study had as objective to adjust regression models by the use of Dummy variables obtained from technological parameters (basic density, diameter at breast height, bark thickness and total volume) of hybrid Eucalyptus clones to predict the longitudinal residual strains (LRS) caused by the growth stresses.

\section{MATERIALS AND METHODS}

One forest plantation was selected in Eldorado do Sul, Rio Grande do Sul state, Brazil. The forest belongs to CMPC Celulose Riograndese and was planted according to an initial spacing of $3 \mathrm{~m} \times 2.7 \mathrm{~m}$, containing 583 treatments of different Eucalyptus clones. Each treatment was composed by 25 trees, which defines one portion. 12 clones with 9 years old were selected due to their basal area recorded with basis on the data from the forest inventory provided by the company (Table 1).

Besides the basal area, good forest form (i.e. trunk straight, no fork, and cylindrical trunk), phenotype, phytosanitary conditions were applied as selection criteria. Additionally, trees located both in the corners of the forest and on sloping ground were avoided.

For the materials characterization, the diameter at breast-height outside bark (DBH, $1.30 \mathrm{~m}$ ) was measured by a metric caliper. The log was debarked at the breastheight and the bark thickness (BT) was determined using a digital caliper with a resolution of $0.01 \mathrm{~mm}$. After that, the longitudinal residual strain (LRS) was determined in living trees, using an extensometer, following the CIRAD-Forêt method. Procedures of debarking, preparation of the measurement site, fixing pins (separated by a distance of $45 \mathrm{~mm}$ ) and the measurements were performed as described following the work by Beltrame et al., (2012). Thus, after the rupture of the wood tissue between the metallic pins, which were drilled by a hand drill, the measurements were found on the digital display of a dial indicator. 
Table 1 - Description of Eucalyptus spp. clones selected for the study.

Tabela 1 -Descrição dos clones de Eucalyptus spp. selecionados para o estudo.

\begin{tabular}{|c|c|c|}
\hline Genetic material & Genealogy & Basal area $\left(\mathrm{m}^{2} \cdot \mathrm{ha}^{-1}\right)$ \\
\hline Clone 1 & E. urophylla $x$ E. grandis & 10.812 \\
\hline Clone 2 & E. urophylla $34062 \times$ E. grandis $M-1$ & 10. 312 \\
\hline Clone 3 & E. urophylla $34062 \times$ E. grandis $M-2$ & 10. 118 \\
\hline Clone 4 & E. saligna $x$ E. saligna 01 & 9. 940 \\
\hline Clone 5 & E. grandis $x$ E. grandis & 9. 446 \\
\hline Clone 6 & E. grandis $x$ E. grandis & 8. 813 \\
\hline Clone 7 & E. urophylla $x$ E. urophylla & 8. 663 \\
\hline Clone 8 & E. urophylla $34058 \times$ E. dunnii $16 L$ & 8. 341 \\
\hline Clone 9 & E. grandis $x$ E. tereticornis & 8. 299 \\
\hline Clone 10 & E. grandis $x$ E. grandis & 6. 908 \\
\hline Clone 11 & E. urophylla $34058 \times$ E. dunnii $17 \mathrm{~L}$ & 5. 869 \\
\hline Clone 12 & E. saligna $x$ E. saligna 01 & 5. 671 \\
\hline
\end{tabular}

Four measurements for each tree were performed following the planting directions (which coincided with the cardinal points), standardizing the measurements. All the measurements were performed without winds to avoid their influence on the data obtained.

Taking advantage of the partial debarking of the trees, which was previously performed in the evaluation of the LRS, the basic density (DB) of each tree was determined by a portable durometer "Pylodin Forest". The instrument measured the trunk strength under drilling of a drill with dimensions of $3 \times 50 \mathrm{~mm}$ (diameter $x$ length). Then, the total height $(\mathrm{H})$ of each tree was measured by an apparatus called Vertex III. The volume of standing tree was calculated (Equation 1) by a relation between $\mathrm{H}, \mathrm{DBH}$ and the artificial form factor.

$$
\mathrm{VOL}=\left(\frac{\pi \times \mathrm{DBH}^{2}}{4}\right) \times \mathrm{H} \times \mathrm{f}_{1,3}
$$

Where: $\mathrm{VOL}=$ total volume $\left(\mathrm{m}^{3}\right) ; \mathrm{DBH}=$ diameter at breast height (m); $\mathrm{H}=$ height $(\mathrm{m}) ; \mathrm{f}_{1,3}=$ artificial form factor.

Dummy variables were defined for each clone, by the sequential regression performed in the statistical software. Then, regression mathematical models were generated to explain each clone, following their properties: DBH, BT, H, BD, VOL and LRS. Besides the Dummy variables added, regression significance, regression coefficient, adjusted coefficient of determination, standard error of estimate (Syx) and coefficient of variation (CV\%) were considered to select the models. Thus, the equation was adjusted supposing that the parameters were fixed, using a regression analysis with ordinary least squares in PROC REG procedure and setting the analysis for the SELECTION $=$ STEPWISE option (includes variables with Forward and delete them with Backward when necessary), which is to form a regression model.

Only independent variables that presented significant $p$ values $(p<0,05)$ were considered. This procedure was done by the hypothesis test for the estimated parameters, using the Student's t-distribution. It was found that the dependent variable needed transformation to stabilize the variance, using the Box-Cox method, which was performed by the power lambda $(\lambda=-0.7)$ estimated by maximum likelihood following the Equation 2 (SCHNEIDER et al., 2009).

$$
\lambda=\mathrm{x} \quad \mathrm{LRS}^{\prime}=\mathrm{LRS}^{\mathrm{x}}
$$

Where: $\lambda=$ lambda; $\operatorname{LRS}^{\mathrm{x}}=$ longitudinal residual strain transformed.

Regression models were created from the Dummy variables and the data obtained from the clones (DB, BT, DBH, H and VOL). Equations 3, 4, 5, 6 and 7 presented the general model for each variable, in which they were subjected to the Stepwise procedure to select the independent variables, which confer precision to the model at the probability of error of $5 \%$.

$(\mathrm{LRS})^{-0,7}=\mathrm{f}(\mathrm{BD}, \mathrm{D} 1, \mathrm{D} 2, \mathrm{D} 3, \mathrm{D} 4, \mathrm{D} 5, \mathrm{D} 6, \mathrm{D} 7$, D8, D9, D10, D11, D12, D1*DB, D2*DB, D3*DB, D4*DB, $\mathrm{D} 5 * \mathrm{DB}, \mathrm{D} 6 * \mathrm{DB}, \mathrm{D} 7 * \mathrm{DB}, \mathrm{D} 8 * \mathrm{DB}, \mathrm{D} 9 * \mathrm{DB}, \mathrm{D} 10 * \mathrm{DB}$, $\mathrm{D} 11 * \mathrm{DB}, \mathrm{D} 12 * \mathrm{DB})(3)$

$(\mathrm{LRS})^{-0,7}=\mathrm{f}(\mathrm{BT}, \mathrm{D} 1, \mathrm{D} 2, \mathrm{D} 3, \mathrm{D} 4, \mathrm{D} 5, \mathrm{D} 6, \mathrm{D} 7, \mathrm{D} 8$, D9, D10, D11, D12, D1*BT, D2*BT, D3*BT, D4*BT, $\mathrm{D} 5 * \mathrm{BT}, \mathrm{D} 6 * \mathrm{BT}, \mathrm{D} 7 * \mathrm{BT}, \mathrm{D} 8 * \mathrm{BT}, \mathrm{D} 9 * \mathrm{BT}, \mathrm{D} 10 * \mathrm{BT}$, $\mathrm{D} 11 * \mathrm{BT}, \mathrm{D} 12 * \mathrm{BT})$

Revista Árvore, Viçosa-MG, v.40, n.6, p.1131-1139, 2016 
$(\mathrm{LRS})^{-0,7}=\mathrm{f}\left(\mathrm{DBH}, \mathrm{D}_{1}, \mathrm{D} 2, \mathrm{D} 3, \mathrm{D} 4, \mathrm{D} 5, \mathrm{D} 6, \mathrm{D} 7\right.$, D8, D9, D10, D11, D12, D1*DBH, D2*DBH, D3*DBH, $\mathrm{D} 4 * \mathrm{DBH}, \mathrm{D} 5 * \mathrm{DBH}, \mathrm{D} 6 * \mathrm{DBH}, \mathrm{D} 7 * \mathrm{DBH}, \mathrm{D} 8 * \mathrm{DBH}$, D9*DBH, D10*DBH, D11*DBH, D12*DBH) (5)

$(\mathrm{LRS})^{-0,7}=\mathrm{f}(\mathrm{H}, \mathrm{D} 1, \mathrm{D} 2, \mathrm{D} 3, \mathrm{D} 4, \mathrm{D} 5, \mathrm{D} 6, \mathrm{D} 7$, D8, D9, D10, D11, D12, D1*H, D2*H, D3*H, D4*H, $\mathrm{D} 5 * \mathrm{H}, \mathrm{D} 6 * \mathrm{H}, \mathrm{D} 7{ }^{*} \mathrm{H}, \mathrm{D} 8 * \mathrm{H}, \mathrm{D} 9 * \mathrm{H}, \mathrm{D} 10 * \mathrm{H}, \mathrm{D} 11^{*} \mathrm{H}$, $\mathrm{D} 12 * \mathrm{H})(6)$

$(\mathrm{LRS})^{-0,7}=\mathrm{f}(\mathrm{VOL}, \mathrm{D} 1, \mathrm{D} 2, \mathrm{D} 3, \mathrm{D} 4, \mathrm{D} 5, \mathrm{D} 6, \mathrm{D} 7$, D8, D9, D10, D11, D12, D1*VOL, D2*VOL, D3*VOL, D4*VOL, D5*VOL, D6*VOL, D7*VOL, D8*VOL, D9*VOL, D10*VOL, D11*VOL, D12*VOL) (7)

Where: $\mathrm{LRS}=$ longitudinal residual strain $(\mathrm{mm})$; $\mathrm{BD}=$ basic density obtained by Pylodin $\left(\mathrm{kg} \cdot \mathrm{m}^{-3}\right)$; $\mathrm{BT}=$ bark thickness $(\mathrm{mm})$; $\mathrm{DBH}=$ diameter at the breast height $(\mathrm{cm}) ; \mathrm{H}=$ total height $(\mathrm{m}) ; \mathrm{VOL}=$ total volume $\left(\mathrm{m}^{3}\right) ; \mathrm{D} 1$ $=$ clone $1, \mathrm{D} 2=$ clone $2, \mathrm{D} 3=$ clone $3, \mathrm{D} 4=$ clone $4, \mathrm{D} 5=$ clone $5, \mathrm{D} 6=$ clone $6, \mathrm{D} 7=$ clone $7, \mathrm{D} 8=$ clone $8, \mathrm{D} 9=$ clone $9, \mathrm{D} 10=$ clone $10, \mathrm{D} 11=$ clone $11, \mathrm{D} 12$ $=$ clone $12, \mathrm{D}=$ Dummy variables.

\section{RESULTS}

The average value of the LRS was $0.111 \mathrm{~mm}$ (Table 2). The clones 8 and 1 presented the extreme values, being the smaller and larger values of 0.076 and $0.202 \mathrm{~mm}$, respectively. Regarding the other properties, their values were inside the range of average values reported by previous studies, similarly to the found for the LRS.
The LRS modeling was performed with Dummy variables and the parameters measured $(\mathrm{BD}, \mathrm{DBH}, \mathrm{BT}$, $\mathrm{H}$ and VOL) to determine the interaction between each other (Table 3).

The regression model selected to the LRS according to the BT (model A) by the Stepwise procedure presented significant value (Table 3 ). Thereby, the inclusion of Dummy variables and their interaction can be seen in the model. The Stepwise procedure found no significant variable for the $\mathrm{BD}$.

The regression model selected to predict the LRS according to $\mathrm{H}$ (Model $\mathrm{C}$ ) presented a larger number of Dummy variables (six variables). Nevertheless, it showed significance within the limit proposed (significance of 0.01). The adjusted coefficient of determination for this model indicated that $59 \%$ of the LRS and $\mathrm{H}$ data were explained. Therefore, among the model proposed in this study, although the model C presented the larger precision ratio compared, it was the model with more Dummy variables added.

Additionally, the model D presented Dummy variables and interactions similar to the model selected for the DBH. This similarity can be explained base on the relation between DBH and VOL, which is directly proportional. Therefore, the DBH and VOL behaviors presented affinity when compared with the LRS.

The statistical coefficients of the models created by the Stepwise procedure to estimate the LRS in function

Table 2 - Average values of the variables measured for each clone.

Tabela 2 - Valores médios das variáveis mensuradas para cada clone.

\begin{tabular}{ccccccc}
\hline Clone & LRS $(\mathrm{mm})$ & $\mathrm{BD}\left(\mathrm{Kg} . \mathrm{m}^{-3}\right)$ & $\mathrm{BT}(\mathrm{mm})$ & $\mathrm{DBH}(\mathrm{cm})$ & $\mathrm{H}(\mathrm{m})$ & $\mathrm{VOL}\left(\mathrm{m}^{3}\right)$ \\
\hline 1 & 0.202 & 474.45 & 10.88 & 22.91 & 33.23 & 0.575 \\
2 & 0.101 & 468.82 & 7.01 & 24.90 & 32.93 & 0.682 \\
3 & 0.089 & 495.86 & 9.22 & 27.12 & 34.32 & 0.830 \\
4 & 0.093 & 431.64 & 7.08 & 26.55 & 34.22 & 0.798 \\
5 & 0.102 & 467.69 & 8.61 & 22.22 & 31.32 & 0.517 \\
6 & 0.156 & 476.71 & 8.69 & 23.09 & 30.72 & 0.541 \\
7 & 0.114 & 540.94 & 11.53 & 24.60 & 33.28 & 0.666 \\
8 & 0.076 & 456.43 & 7.88 & 23.73 & 31.15 & 0.581 \\
9 & 0.107 & 484.59 & 5.78 & 22.88 & 31.72 & 0.559 \\
10 & 0.094 & 437.83 & 6.78 & 24.41 & 30.96 & 0.619 \\
11 & 0.093 & 477.83 & 7.11 & 23.38 & 30.99 & 0.564 \\
12 & 0.108 & 450.79 & 6.07 & 22.78 & 32.91 & 0.564 \\
Average & 0.111 & 471.96 & 8.05 & 24.05 & 32.31 & 0.625 \\
\hline
\end{tabular}

Where: $\mathrm{LRS}=$ longitudinal residual strain; $\mathrm{BD}=$ basic density; $\mathrm{BT}=$ bark thickness; $\mathrm{DBH}=$ diameter at breast height; $\mathrm{H}=$ total height; $\mathrm{VOL}=$ total volume

Em que: $D R L=$ deformação residual longitudinal; $D B=$ densidade básica; $E C=$ espessura de casca; DAP = diâmetro a altura do peito; $H=$ altura total; $V O L=$ volume da árvore em pé. 
Table 3 - Regression model and statistical coefficients obtained by the stepwise procedure to describe the DRL, according to the EC (Model A), DAP (Model B), H (Model C) and VOL (Model D) and variables Dummy.

Tabela 3 - Modelo de regressão e coeficientes estatísticos obtidos pelo procedimento Stepwise, para descrever a DRL, em função da EC (Modelo A), DAP (Modelo B), H (Modelo C) e VOL (Modelo D) e das variáveis Dummy.

\begin{tabular}{|c|c|c|c|c|c|}
\hline \multicolumn{2}{|r|}{ Model } & \multicolumn{4}{|c|}{ Statistics } \\
\hline & & $F^{\prime}$ & Prob $>F$ & $\mathrm{CV} \%$ & $\mathrm{R}_{\mathrm{aj}}^{2}$ \\
\hline $\mathrm{A}$ & $\mathrm{DRL}^{-0.7}=\mathrm{b}_{0}+\mathrm{b}_{1} * \mathrm{EC}-\mathrm{b}_{2} * \mathrm{D} 1-\mathrm{b}_{3}{ }^{*} \mathrm{D} 6-\mathrm{b}_{4} *(\mathrm{D} 7 * \mathrm{EC})+\mathrm{b}_{5} *(\mathrm{D} 8 * \mathrm{EC})$ & 35.27 & $<0.001$ & 13.6 & 0.55 \\
\hline $\mathrm{B}$ & $\begin{array}{l}\mathrm{DRL}-0.7=\mathrm{b}_{0}+\mathrm{b}_{1} * \mathrm{dap}-\mathrm{b}_{2}^{2} * \mathrm{D} 1-\mathrm{b}_{3} * \mathrm{D} 6+\mathrm{b}_{4} * \mathrm{D} 8+\mathrm{b}_{5} * \mathrm{D} 9-\mathrm{b}_{6}^{*}(\mathrm{D} 7 * \mathrm{dap})- \\
\mathrm{b}_{7} * \text { (D9*dap) }\end{array}$ & 29.37 & $<0.001$ & 13.1 & 0.58 \\
\hline $\mathrm{C}$ & $\begin{array}{l}\mathrm{DRL}-0.7=\mathrm{b}_{0}+\mathrm{b}_{1} * \mathrm{H}-\mathrm{b}_{2} * \mathrm{D} 1-\mathrm{b}_{3}^{*} \mathrm{D} 6+\mathrm{b}_{4} * \mathrm{D} 9+\mathrm{b}_{5} *(\mathrm{D} 6 * \mathrm{H})-\mathrm{b}_{6} *(\mathrm{D} 7 * \mathrm{H})+ \\
\mathrm{b}_{7}^{*}(\mathrm{D} 8 * \mathrm{H})-\mathrm{b}_{8}^{*}(\mathrm{D} 9 * \mathrm{H})-\mathrm{b}_{9}^{*}(\mathrm{D} 12 * \mathrm{H})\end{array}$ & 23.60 & $<0.001$ & 13.0 & 0.59 \\
\hline $\mathrm{D}$ & $\begin{array}{l}\mathrm{DRL}-0.7=\mathrm{b}_{0}+\mathrm{b}_{1}^{*} \text { VOL }-\mathrm{b}_{2} * \mathrm{D} 1-\mathrm{b}_{3} * \mathrm{D} 6+\mathrm{b}_{4} * \mathrm{D} 8+\mathrm{b}_{5} * \mathrm{D} 9-\mathrm{b}_{6} *(\mathrm{D} 7 * \mathrm{VOL})- \\
\mathrm{b}_{7}^{*}(\mathrm{D} 9 * \mathrm{VOL})\end{array}$ & 29.54 & $<0.001$ & 13.1 & 0.58 \\
\hline
\end{tabular}

Where: $\mathrm{LRS}=$ longitudinal residual strain; $\mathrm{BD}=$ basic density; $\mathrm{BT}=$ bark thickness; $\mathrm{DBH}=$ diameter at breast height; $\mathrm{H}=$ total height; VOL = total volume; $b_{0}, b_{1} b_{2} b_{3} b_{4}, b_{5}, b_{6}, b_{7} b_{8}, b_{9}=$ coefficients of the model; D1, D6, D7, D 8 = clones 1, 6, 7 e 8; F' = F ratio for the model; Prob. $>\mathrm{F}=$ probability of error; $\mathrm{CV}=$ coefficient of variation; $\mathrm{R}^{2}$ = adjusted coefficient of determination.

Em que: $D R L=$ deformação residual longitudinal; $E C=$ espessura de casca; $D A P=$ diametro a altura do peito; $H=$ altura total; $V O L$ $=$ volume da árvore em pé; $b_{0}, b_{1} b_{2,} b_{3} b_{4} b_{5} b_{6} b_{7} b_{8} b_{9}=$ coeficientes do modelo; D 1, D6, D7, D8 = clones $1,6,7$ e 8; F'= valor de F calculado para o modelo; Prob. $>F \stackrel{F}{=}$ nivel de probabilidade de erro; $C V=$ coeficiente de variação; $R 2 a j$. $=$ coeficiente de determinação ajustado.

of BT DBH, H and VOL using Dummy variables and their interactions are described in the Table 4 . The variables inserted in the model showed significance for BT. Thus, LRS values can be described by some Dummy variables (D1, D6, D7 and D8) from the clones $1,6,7$ and 8 . Regarding the $\mathrm{DBH}$, the Dummy variables D1, D6, D7, D8 e D9 were included in the model.

According to the statistical coefficients presented in the Table 4 for the variable $\mathrm{H}$, all of the variables found in the model are significant. Therefore, the LRS can be estimated in function of $\mathrm{H}$ values through the following Dummy variables and their interactions: D1, D6, D9, D6, D7, D8, D9 and D12. For the VOL, there were the clones $1,6,7,8$ and 9 to predict the relation with the LRS, presenting significant values for the independent variables.

The behaviors of BT, DBH, H and VOL were plotted based on the values of coefficients for each variable determined. Afterwards, these data were recomputed to the original form, withdrawing the power lambda $(\lambda=-0.7)$ in order to facilitate the understanding of the behavior of the variables (Figure 1).

The clones 1, 6, 7 and 8 presented different behaviors about LRS and BT based on the slope of each straight line estimated, as can be seen in the Figure 1-A. In the others parts of the Figure A, it was noted that there were no significant differences among the clones 2 , $3,4,5,10,11$ and 12, which can be represented by the straight line of the clone 2 .
Regarding the LRS and BT data, it was noted that the clones presented the same behaviors, whereas the BT increases, the LRS decreases, except for the clone 9. Thus, it was found a significant influence of the BT on the LRS, which can be estimated by the BT. However, the BT presented significant correlation with the DBH and hence, it was supposed that both act similarly on the LRS values.

Regarding the Figure 1-B, it was found that the DBH presented significant influence on the LRS values. Based on the model previously presented in the Table 3, it is possible to predict the LRS values in function of the $\mathrm{H}$ for the clones, as can be seen in the Figure 1-C. Regarding other variables, it was noted that the behavior of LRS in function of $\mathrm{H}$ for the clones presented a smaller variation than the angles of straight lines from the clones $2,7,8$ and 12 .

Thus, the H presented a low influence on the LRS represented by the angles of the straight line of the clones 2, 7, 8 and 12. Regarding the Figure 1-C, the clones 3, 4, 5, 10 and 11 are represented by the straight line of the clone 2 , because they do not present statistical differences compared to each other. On another hand, clone 6 presented a high strain level for the same heights, which can be attributed to values estimation, once these values were not directly measured.

This behavior for VOL was expected (Figure 1-D), once the selected model presented the same variables compared to the DBH. It was found that the LRS tends to decrease with the increase of VOL, which was also

Revista Árvore, Viçosa-MG, v.40, n.6, p.1131-1139, 2016

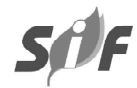


Table 4 - Parameters of the statistical model to estimate the LRS, according to Dummy variables, BT, DBH, H and VOL. Tabela 4 - Parâmetros estatísticos do modelo gerado para estimar a DRL, em função da EC, DAP, He VOL e das variáveis Dummy.

\begin{tabular}{|c|c|c|c|c|}
\hline Coefficients of the model & Coefficients values & Syx & $\mathrm{t}$ & Prob $>t$ \\
\hline \multicolumn{5}{|c|}{$\mathrm{BT}$} \\
\hline $\mathrm{b}_{0}$ & 4.55120 & 0.23917 & 19.03 & $<0.0001$ \\
\hline$b_{1}$ & 0.08468 & 0.03192 & 2.65 & 0.0089 \\
\hline D1 & -2.31521 & 0.23769 & -9.74 & $<0.0001$ \\
\hline D6 & -1.48643 & 0.21185 & -7.02 & $<0.0001$ \\
\hline D7BT & -0.07223 & 0.02158 & -3.35 & 0.0010 \\
\hline D8BT & 0.11545 & 0.02598 & 4.44 & $<0.0001$ \\
\hline \multicolumn{5}{|c|}{$\mathrm{DBH}$} \\
\hline $\mathrm{b}_{0}$ & 3.34282 & 0.48332 & 6.92 & $<0.0001$ \\
\hline$b_{1}$ & 0.07573 & 0.01956 & 3.87 & 0.0002 \\
\hline D1 & -1.92019 & 0.20170 & -9.52 & $<0.0001$ \\
\hline D6 & -1.29025 & 0.20120 & -6.41 & $<0.0001$ \\
\hline D8 & 1.00372 & 0.19995 & 5.02 & $<0.0001$ \\
\hline D9 & 4.76123 & 1.39823 & 3.41 & 0.0009 \\
\hline D7DBH & -0.02046 & 0.00807 & -2.54 & 0.0124 \\
\hline D9DBH & -0.21585 & 0.06001 & -3.60 & 0.0004 \\
\hline \multicolumn{5}{|c|}{$\mathrm{H}$} \\
\hline $\mathrm{b}_{0}$ & 2.46730 & 1.13098 & 2.18 & 0.0309 \\
\hline $\mathrm{b}_{1}$ & 0.08605 & 0.03478 & 2.47 & 0.0146 \\
\hline D1 & -2.16971 & 0.20198 & -10.74 & $<0.0001$ \\
\hline D6 & -10.85927 & 4.85101 & -2.24 & 0.0268 \\
\hline D9 & 10.74699 & 3.30578 & 3.25 & 0.0015 \\
\hline $\mathrm{D} 6 \mathrm{H}$ & 0.31080 & 0.15731 & 1.98 & 0.0499 \\
\hline $\mathrm{D} 7 \mathrm{H}$ & -0.01851 & 0.00608 & -3.05 & 0.0028 \\
\hline $\mathrm{D} 8 \mathrm{H}$ & 0.03183 & 0.00657 & 4.85 & $<0.0001$ \\
\hline $\mathrm{D} 9 \mathrm{H}$ & -0.34824 & 0.10374 & -3.36 & 0.0010 \\
\hline $\mathrm{D} 12 \mathrm{H}$ & -0.01512 & 0.00610 & -2.48 & 0.0144 \\
\hline \multicolumn{5}{|c|}{ VOL } \\
\hline $\mathrm{b}_{0}$ & 4.35344 & 0.22581 & 19.28 & $<0.0001$ \\
\hline $\mathrm{b}_{1}$ & 1.29240 & 0.33050 & 3.91 & $<0.0001$ \\
\hline D1 & -1.93915 & 0.20054 & -9.67 & $<0.0001$ \\
\hline D6 & -1.25231 & 0.20219 & -6.19 & $<0.0001$ \\
\hline D8 & 1.03745 & 0.20029 & 5.18 & $<0.0001$ \\
\hline D9 & 2.06955 & 0.67105 & 3.08 & 0.0025 \\
\hline D7VOL & -0.78539 & 0.29174 & -2.69 & 0.0080 \\
\hline D9VOL & -4.02115 & 1.12889 & -3.56 & 0.0005 \\
\hline
\end{tabular}

Where: $\mathrm{Syx}=$ standard error of the estimation; $\mathrm{t}=\mathrm{t}$ value; Prob $>\mathrm{t}=$ probability of error.

Em que: Syx = erro padrão da estimativa; $t=$ valor de $t$ calculado; Prob, $>t=$ nível de probabilidade do erro

found for all clones, except for clone 9. Clone 1 showed high values for the LRS based on all analyses.

\section{DISCUSSION}

The LRS values are within the range of averages reported by previous studies (between 0.065 and 0.145 $\mathrm{mm}$ ), which also analyzed the Eucalyptus wood (SOUZA et al., 2003; CARDOSO JUNIOR et al., 2005; TRUGILHO et al., 2006). Similarly, BT, DBH, H and VOL were within the average obtained on Eucalyptus trees with similar ages, according to LIMA et al., 2004; BOTREL et al., 2007; CARVALHO et al., 2010; BELTRAME et al., 2012. These comparisons indicated that the development of the trees from this study occurred under suitable edafoclimatic conditions, which confer a normal physiological activity to them (YANG et al., 2002).

The genetic material correspondent to clone 1 shall be discarded when the objective is to produce defectfree lumbers or clean logs, due to its LRS levels. Regarding the fact that Dummy variables were not found for the 


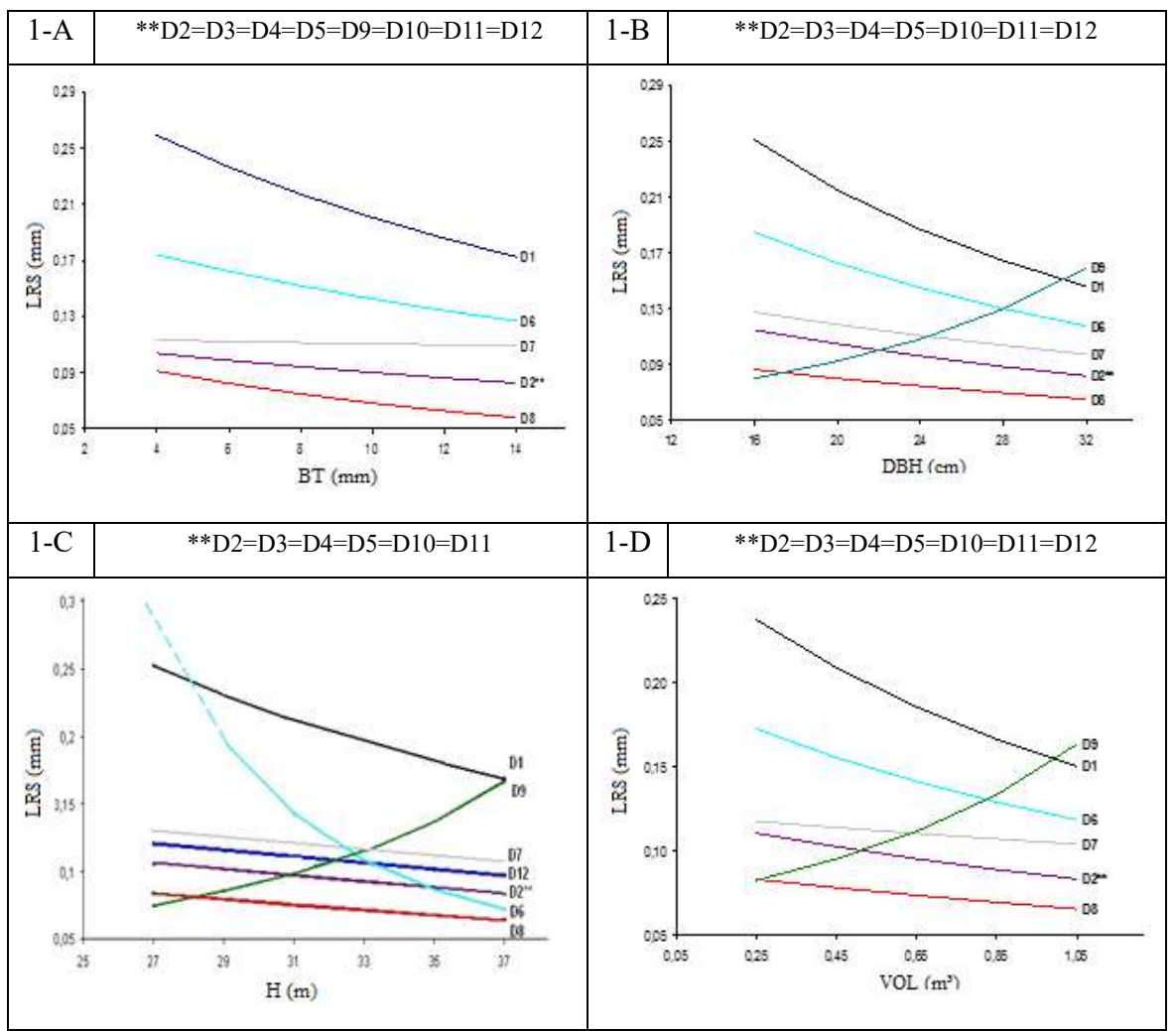

Figure 1 - Behavior of DRL by means of the modeled equations in function of Dummy variables, BT, DBH, H and VOL. Figura 1 - Comportamento da DRL, por meio das equações modeladas, em função da EC, DAP, He VOL e das variáveis Dummy.

LRS prediction based on the BD, it is supposed that the equipment used to measure this parameter (durometer Pylodin) presents low precision, which probably harmed the correlation between LRS and BD. Such result is confirmed in previous studies, as McKenzie et al. (2003) and Gouvêa et al. (2011), who found low correlations between the BD and the strength to drill obtained by Pylodin.

Similarly to model A, the model used to predict the LRS in function of DBH (Model B) presented significance after the insertion of Dummy variables and their interactions. Additionally, the coefficient of variation presented as uitable result to adjust the model (PIMENTEL GOMES, 1990).

The model presented to predict the LRS according to the VOL (Model D) also presented significance. Similar to the other mathematical models presented in the Table 3, the model presented a coefficient of variation between low and medium following the classification proposed by Pimentel Gomes (1990), which indicates variability in this data.

The trees of larger DBH levels presented smaller growth stresses levels (Figure 1-B), which probably is related to genetic materials with low probability of presenting defects, resulting in wood logs with high quality to be subjected to mechanical processing. This result can be explained based on the slenderness (relation between height and diameter) of their trunk, once the trunk tissues of slender trees (height $>>$ diameter) are probably more intensively required during its development, due to the action of winds and other external loads.

Similar to the correlations obtained in this study, Beltrame et al. (2013), studying trees Eulcayptus saligna, found significant correlation between BT and LRS, although it was low (0.1948). Furthermore, the same authors confirmed the significance between BT and DBH found in this study, pointing to a positive and significant correlation (0.5497).

Revista Árvore, Viçosa-MG, v.40, n.6, p.1131-1139, 2016 
Regarding the functional relation between $\mathrm{DBH}$ and LRS, Valencia et al. (2011) reported that the processing of wood logs from old trees tends to present a decrease in the issues from the growth stresses due to their larger diameter, because the stresses are distributed in a larger radius. As found in the present study, Carvalho et al. (2010) found positive and significant correlation between LRS and DBH for trees from Eucalyptus urophylla and Corymbia citriodora, both analyzed at 13 years old. This influence of the DBH on the LRS for trees from Corymbia citriodora and Eucalyptus urophylla was also found by Gonçalves (2007), analyzing 15 years old trees.

As the present study has found, the low influence of H on the LRS was previously found by Gonçalvez (2007) analyzing trees from Corymbia citriodora, by Trugilho (2005) analyzing clones from Eucalyptus genus and by Lima et al. (2004) analyzing hybrid clone from Eucalyptus genus.

Regarding the relation of $\mathrm{DBH}, \mathrm{H}$ and VOL with the LRS, it was found that clone 9 was discrepant compared to the others, which probably is related to its genealogy because it is the only hybrid clone from Eucalyptus tereticornis. This inverse trend presented by the clone 9 (Figure 1-B, C and D) also was found by trugilho (2005), analyzing 8,15 and 19 years old trees from Eucalyptus dunnii. Thus, since this study did not aim to report findings about genetic factors, it is suggested that this theme should be approached in future researches.

In general, it was found that the adjusted mathematical models were suitable to predict the LRS by dendrometric properties from trees, once they presented better statistical parameters than other models proposed in previous studies (LIMA et al., 2004; FANG et al., 2008; MONTEOLIVA; HERNANDEZ, 2014).

\section{CONCLUSIONS}

The LRS from growth stresses for Eucalyptus spp. varied when compared between the clones, which explain the need of a specific genetic selection according to their final use;

The dendrometric properties (BT, DBH, H and VOL) of each clone were able to describe the behavior of their respective LRS;

The use of Dummy variables allows the simultaneous adjustment of equations, considering different clones from Eucalyptus spp. Therefore, this statistical tool allows the evaluation of the behavior of Euclayptus clones according to some of their morphological characteristics. However, it is highlighted that there are significant differences in the behavior of certain hybrids.

\section{REFERENCES}

AGGARWAL, P.; CHAUHAN, S. Longitudinal growth strains in five clones of Eucalyptus tereticornis Sm. Journal of Forestry Research, v.24, n.2, p.339-343, 2013.

BELTRAME, R.; LAZAROTTO, M.; HASELEIN, C.R.; SANTINI, E.J.; SCHNEIDER, P. R.; AGUIAR, A.M. Determinação das deformações residuais longitudinais decorrentes das tensões de crescimento em Eucalyptus spp. Ciência Florestal, v.22, n.2, p.343-351, 2012.

BELTRAME, R.; MATTOS, B.D.; HASELEIN, C.R.; SANTINI, E.J.; GATTO, D.A.; CADEMARTORI, P.H.G.; PEDRAZZI, C. Evaluation of longitudinal residual strain of Eucalyptus saligna Smith. wood. Scientia Forestalis, v.41, n.97, p.95101, 2013.

BOTREL, M.C.G.; SILVA, J.R.M.; TRUGILHO, P.F.; ROSADO, S.C.S.; FERNANDES, B.R. Ganho genético em propriedades físicas e mecânicas de clones de Eucalyptus. Scientia Forestalis, n.76, p.13-19, 2007.

CARDOSO JR., A.A.; TRUGILHO, P.F.; LIMA, J.T.; ROSADO, S.C.S.; MENDES, L.M. Deformação residual longitudinal em diferentes espaçamentos e idades em clone de híbrido de Eucalyptus.

Cerne, v.11, n.3, p.218-224, 2005.

CARVALHO, A.M.; GONÇALVES, M.P.M.; AMPARADO, K.F.; LATORRACA, J.V.F.; GARCIA, R.A. Correlações da altura e diâmetro com as tensões de crescimento em árvores de Corymbia citriodora e Eucalyptus urophylla. Revista Árvore, v.34, n.2, p.323-331, 2010.

CUNIA, T. Dummy variables and some of their uses in regression analysis. Nancy: IUFRO, 1973. 146p.

FANG, C.H.; GUIBAL, D.; CLAIR, B.; GRIL, J.; LIU, Y.M.; LIU, S.Q. Relationships between growth stress and wood properties 1 in Poplar 2 
I-69 (Populus deltoides Bartr. cv."Lux" ex I-69/55). Annals of Forest Science, v.65, n.3, p.307, 2008.

GONÇALVES, M.P.M. Correlações da altura e diâmetro com tensões de crescimento em árvores de Eucalyptus citriodora Hook e Eucalyptus urophylla S. T. Blake. 2007. 31f. Monografia (Graduação em Engenharia Florestal) - Universidade Federal Rural do Rio de Janeiro, Seropédica, 2007.

GOUVÊA, A.F.G.; TRUGILHO, P.F.; GOMIDE, J.L.; SILVA, J.R.M.; ANDRADE, C.R.; ALVES, I.C.N.

Determinação da densidade básica da madeiras de Eucalyptus por diferentes métodos não

destrutivos. Revista Árvore, v.35, n.2, p.349358,2011 .

LIMA, J.T.; TRUGILHO, P.F.; ROSADO S.C.S.; CRUZ, C.R. Deformações residuais longitudinais decorrentes de tensões de crescimento em Eucaliptos e suas associações com outras propriedades. Revista Árvore, v.28, n.1, p.107-116, 2004.

MCKENZIE, H.M.; SHELBOURNE, C.J.A.; KIMBERLEY, M.O.; MCKINLEY, R.B.; BRITTON, R.A.J. Processing young plantation-grown Eucalyptus nitens for solid-wood products. 2: Predicting product quality from tree, increment core, disc, and 1-M billet properties. New Zealand Journal of Forestry Science, v.33, n.1, p.79-113, 2003.

MONTEOLIVA, S.; HERNANDEZ, M. Tensiones de crecimiento en Eucalytpus dunnii Maiden.: parámetros dendrométricos y anatomía de la madera. Revista Árvore, v.38, n.4, p.755-763, 2014.

PIMENTEL GOMES, F. Curso de estatística experimental. 13.ed. Piracicaba: USP, 1990. $467 \mathrm{p}$.

RAYMOND, C.A.; KUBEA, P.D.; PINKARDA, L.; SAVAGEA, L.; BRADLEYA, A.D. Evaluation of non-destructive methods of measuring growth stress in Eucalyptus globulus: relationships between strain wood properties and stress. Forest Ecology and Management. v.190, n.2-3, p.187-200, 2004.

ROCHA, M.P. Eucalyptus grandis Hill ex Maiden e Eucalyptus dunnii Maiden como fontes de matéria prima para serraria. 2000. 185f. Tese (Doutorado em Engenharia Florestal) - Universidade Federal do Paraná, Curitiba, 2000

SCHNEIDER, P.R. Manejo florestal: planejamento da produção florestal. Santa Maria: UFSM, 2009. 613p.

SOUZA, M.A.M.; TUGILHO, P.F.; LIMA, J.T.; ROSADO, S.C.S. Deformação residual longitudinal e sua relação com algumas características de crescimento e da madeira em clones de Eucalyptus. Floresta, v.33, n.3, p.275-284, 2003.

TRUGILhO, P.F. Tensão de crescimento em árvores vivas de clones Eucalyptus spp. e de Eucalyptus dunnii Maiden e propriedades da sua madeira. 2005. 137f. Tese (Pós-Doutorado em Ciências Florestais) - Universidade Federal do Paraná, Curitiba, 2005.

TRUGILHO, P.F.; LIMA, J.T.; PÁDUA, F.A.; SORAGI, L.C.; ANDRADE, C.R. Deformação residual longitudinal (DRL) e tangencial (DRT) em seis clones de Eucalyptus spp. Cerne, v.12, n.3, p.279-286, 2006.

VALENCIA, J.; HARWOOD, C.; WASHUSEN, R.; MORROW, A.; WOOD, M.; VOLKER, P. Longitudinal growth strain as a log and wood quality predictor for plantation-grown Eucalyptus nitens sawlogs. Wood Science and Technology, v.45, n.1, p.15-34, 2011.

YANG, J.L.; FIFE, D.; WAUGH, G.; DOWNES, G.; BLACKWELL, P. The effect of growth strain and other defects on the sawn timber quality of 10year-old Eucalyptus globulus Labill.

Australian Forestry, v.65, n.1, p.31-37, 2002. 